\title{
Public Theology in pluralistic societies? Lessons from the theology of Etienne de Villiers
}

\author{
Author: \\ Nico Koopman ${ }^{1}$ \\ Affiliation: \\ ${ }^{1}$ Department of Systematic \\ Theology, University of \\ Stellenbosch, South Africa \\ Correspondence to: \\ Nico Koopman \\ Email: \\ nkoopman@sun.ac.za \\ Postal address: \\ 171 Dorp Street, \\ Stellenbosch 7600, \\ South Africa \\ Dates: \\ Received: 30 July 2012 \\ Accepted: 04 Oct. 2012 \\ Published: 06 Dec. 2012 \\ How to cite this article: \\ Koopman, N., 2012, 'Public \\ Theology in pluralistic \\ societies? Lessons from \\ the theology of Etienne de \\ Villiers', Verbum et Ecclesia \\ 33(2), Art. \#773, 6 pages. \\ http://dx.doi.org/10.4102/ \\ ve.v33i2.773
}

C 2012. The Authors. Licensee: AOSIS OpenJournals. This work is licensed under the Creative Commons Attribution License.
This article discussed the meaning and significance of the theological contribution of Etienne de Villiers for the task of prophetic public theology in pluralistic societies. It was argued that De Villiers's theology enriched public theology in a variety of ways. De Villiers convincingly argued that Christian morality does have unique contents. These unique contents enrich and deepen discussions in the pluralistic public domain. De Villiers also showed that Christians can enter the public domain from the perspective of so-called thicker theological convictions like sin and love. De Villiers emphasised the participation of Christians in so-called technical discourses. This implied that Christians strive to make their convictions as far as possible intellectually accessible to a pluralistic audience, that Christians strive for moral consensus, sound moral decision-making, influencing of the public opinion and participation in policymaking processes in pluralistic life. This technical discourse with the aim to reach moral consensus and to impact on policymaking processes should also be practiced within Christian communities where a plurality of moral views, even conflicting views, exist. This quest for decision-making, consensus and impacting on public policy are to be advanced in the ecumenical Christian family, and even between Christians and other religions.

\section{Introduction}

The theological work of Etienne De Villiers helps us in various ways to conduct public theology in pluralistic societies. The notion of public theology is used in manifold ways. In this article it is simply used to refer to the quest of South Africans churches and theologians to redefine and contextualise the calling and role of Christian faith and churches in public life. This redefinition takes place in a context of a pluralistic society with an inclusive democracy, where manifold challenges are to be addressed. De Villiers has discussed the faces, causes and possible remedies for these challenges in various publications (De Villiers 2011a:5-13).

Based on the notion of the threefold office of Christ we can identify three forms of public theology, namely a prophetic public theology, a priestly public theology and a royal-servant public theology.

It is especially with regard to a prophetic public theology that De Villiers offers assistance. Prophetic public theology is done in five interdependent modes, namely as spelling out the vision of a redeemed and new society (habitat) with people of new habits (habitus) who engage in new decisions and acts. Secondly a prophetic public theology offers criticism about our failure to materialise the vision of a new reality. Telling of the stories of suffering and hope of people is a third dimension of prophetic public theology. The last two modes of a prophetic public theology are the participation with role-players of other disciplines and spheres of life in the technical analysis of public issues, as well as the appropriate involvement in policy-making processes. ${ }^{1}$

De Villiers assists public theological discourses in a variety of ways. He firstly helps us to draw in constructive ways upon the contents of Christian morality when we participate in pluralistic public discussions. He namely develops an argument in favour of the uniqueness of the contents of Christian morality. De Villiers assists public theology also by showing how an appeal to the so-called thicker theological convictions, amongst others the notions of sin and love, enriches pluralistic public discussions. De Villiers thirdly advances public theological discourses by providing a rationale and method for participation in technical analysis as a crucial form of prophetic discourse. In the technical discourse thicker theological convictions are made as far as possible rationally accessible to those outside the Christian tradition. The technical discourse also facilitates the quest for moral consensus, moral decision-making and policy-making processes, both in broader pluralistic societies and within churches - and even other religious traditions with their plurality of and often conflicting moral positions.

1.For fuller discussions of these five modes of prophetic public theology see Koopman $(2009 ; 2010)$. 


\section{A specific Christian contribution in pluralistic public discourse}

De Villiers's emphasis on the technical discourse helps public theological discourse in pluralistic societies to establish the specific Christian contribution to public discourses in a pluralistic context.

De Villiers $(1978 ; 2005: 531-532)$ opposes the idea that only a secular morality can be accommodated in pluralistic public discourses. He opposes the idea of someone like his Doktor Vater, Harry Kuitert, who pleads in favour of an autonomous secular morality that is independent of religious convictions. ${ }^{2}$ He cannot accept Kuitert's idea, which is echoed by many theologians, that religion is not the mother of morality, but only its protector and feeder. [Godsdiens is nie die moeder van moraal nie, maar slegs sy hoeder en voeder.]

Kuitert's definition of morality is illuminated by a distinction that Dutch ethicist, Bert Musschenga (1989:166-173), uses with regard to morality. He distinguishes between the socalled narrow and broad moralities. Kuitert (1988b:31) states that broad morality includes the personal ideal that people want to realise through their behaviour and actions. It means that people are more interested to live virtuous lives than to obey specific rules. Narrow or social morality, according to Musschenga (1989:169ff.) and Kuitert (1988b:31-32), refers to the moral directives that are crucial for the peaceful coexistence of human beings with different ideals and interests. According to Musschenga (1989:166) the narrow morality, unlike the broad morality, has universal pretensions. It is not based in particular communities, religions and traditions, but in something that humans have in common, namely rational capacities and a focus on own interests.

Kuitert (1988b:31-32) describes narrow or social morality as a minimum and indispensable morality. It has to do only with those minimum principles and guidelines without which a society cannot exist peacefully. These principles can be justified rationally, that means understandable and convincing reasons can be offered for them. Because of this limited feature of narrow morality and because of its rational accessibility this type of morality, according to Kuitert, enhances the quest for moral consensus in a pluralistic context.

For Kuitert (1988c:135) morality should not focus on the personal ideals of the good life. It should only focus on the questions about what is good and bad, right and wrong, what ought to be done and what not. Good and bad is determined only in terms of what is enhancing the lives and well-being and harmony of a plurality of people. Kuitert's preference for morality as narrow or social morality already betrays his understanding of the relationship between morality and religion. This theme is investigated in the next paragraph.

According to Kuitert (1974b:76-75; 1988a:107) morality functions independently from religion. Religion is not the mother of morality, but the protector, feeder and facilitator thereof. Morality was not brought into being by religion. Morality came into existence through rational human processes. ${ }^{3}$ In a rational way humans work out the means of living together in harmony. ${ }^{4}$ We formulate both broad moral principles and specific moral guidelines that serve our quest for a peaceful coexistence. In changing circumstances we formulate new moral guidelines on the basis of the universally accepted broader moral principles. Religion did not bring morality into being. Neither does it contribute something unique to the contents of morality. It is not the mother of morality. However, as protector of morality religion has something to do with morality.

Kuitert (1984:216-218) demonstrates how religions fulfil their role as protector, facilitator and feeder of morality. Religion merely intensifies the motive that people have developed rationally for a specific choice. Religion lends more of a personal involvement to our choice and also a clear vision that encourages that choice and behaviour, for example, in the case of Christians the vision of the coming kingdom of God.

According to Kuitert religion gives a unique framework of understanding or comprehension to morality. In the case of Christianity the doctrine of humans as the image of God helps to illuminate the concept of human worth and dignity (Kuitert 1981:258). Christ's commandment of love for the enemy does not offer something new to the contents of morality, but merely indicates that something more than the usual should be strived for (Kuitert 1985:149). Religion also serves to help prioritise moral issues. Love, for instance, is for moral affairs a more important norm than order.

Some important conclusions about Kuitert's understanding of the relationship between religion and morality can be drawn. Moral contents do not need religion. Religion contributes nothing to the contents of morality. Religious tradition mainly has a motivational and meaning-giving function with regard to morality. Moreover, this motivation is further limited to the level of doing the good and to be equipped to do the good. Religion does not even give indispensable motivation for the actual moral decision. Decisions are made in terms of rational motives.

Unlike thinkers like Kuitert, who limit the role of religion with regard to moral positions to that of providing a meaninggiving framework, an inspiration, an encouragement, nurturing, and strengthening of decisions that can be taken independent of religious convictions, De Villiers argues that our religious convictions also do determine the contents of our moral choices. De Villiers spells out the specific ways in which Christian religious convictions determine the contents of moral positions.

3.According to Kuitert (1988a:108) morality is autonomous and secular. You need not be a Christian to write an ethics that describes what ought and what ought not to be. be a Christian to wite an thics mill as it is expressec Consequently an appeal to God's will as it is expressed in the Bible (Kuitert 1974a,
is not essential for making moral decisions.

4. Kuitert would admit that it is God who grants humans rational capacities to work out moral principles and guidelines. God gives us this insight in terms of the creational redemption which is to be distinguished from the eternal salvation in Jesus Christ (1985:141-153). 
He (De Villiers 1978:198) acknowledges the similarities between the moral views of Christians and that of other religions and secular world views. The moral contents of Christians reflect resemblances with that of other religious and secular traditions. The contents of Christian morality are also determined by so-called non-religious factors. Christian faith does not oppose constructive rational reflection about morality. De Villiers (1978:194) refers, amongst others, to Jesus Christ who, according to the gospels, appeals to people to use their rational capacities to show moral discernment. Jesus assumed some insight in his audiences into the fundamental moral principles that guide human life.

$\mathrm{He}$, however, argues in favour of the unique contents of Christian morality. De Villiers describes various dimensions of the uniqueness of the contents of Christian morality.

De Villiers (1978:206) argues that the biblical authors borrowed from the moral insights of other religions and cultures. They made a critical selection from these moral contents. Punishments that caused distortion of the body were not practised in Israel. Paul borrowed from the Stoics and other groupings, but he eliminated some of their central convictions, amongst others glorification and idolisation of the homeland, resistance to the single, unmarried state, and room for so-called paid marriages and polygamy.

De Villiers (1978:206) further argues, that based on the love commandment, Christians give a different prioritisation to moral positions. A variety of ceremonial prescriptions in rabbinic ethics were dealt with through the lenses of the priority of the love commandment in early Christian ethics. In Christian thinking the love commandment is universalised and radicalised to include the enemy (De Villiers 1978:207-208).

This prioritisation also implies that Christians, more than other groups, view human life as a life of worth and dignity (De Villiers 1978:206). De Villiers (1978:207-208) mentions that the uniqueness of Christian morality also rests in the fact that moral practices gained increasing importance in redemption history. Jesus performed the moral act of redemption on the Sabbath and Paul ensures that the practice of circumcision does not fulfil the morally negative role of excluding people from communion. The comprehensive redemption in Christ, the covenantal relationship between God and humans, the salvation implied in the reign of God and the emphasis of human beings as being created in the image of God are unique Christo-centric and Trinitarian categories which contribute to the unique contents of Christian morality.

In Christian ethics the virtue of humility was strange to the ethical thinking of surrounding cultures like that of the Stoics. Throughout the centuries the Christian emphasis on humility impacted on the ethics of surrounding cultures, and together with notions such as the creation of humans in the image of God, informed modern human dignity and human rights discourses with their emphasis on the equal worth and dignity of all people (De Villiers 1978:208-209).
We might conclude that for De Villiers the uniqueness of the contents of Christian morality resides in the Christo-centric focus of Christians and in the love commandment, which lead to a unique selection, elimination and prioritisation of moral contents that also exist outside the Christian faith. Public theological discourse in pluralistic societies can be enriched if we acknowledge the contribution of uniqueness that Christian faith can make to public discourses, not only in terms of providing meaning-giving frameworks and inspiration, but also with regard to the moral contents. De Villiers provides stimuli that deserve more exploration.

\section{Thicker theological convictions in the pluralistic public domain}

De Villiers (1995:566) is consequently of the opinion that we should enter public pluralistic discussions from the perspective of so-called thicker theological convictions. He even suggests that we attempt to describe and analyse social problems in terms of the insights by the Christian faith. He, for instance, suggests that we describe poverty in this thicker theological manner. This would entail, amongst others, that we identify poverty as an expression of our sinfulness. Poverty has various causes, but one of them - public theology would suggest - is the corruptio totalis [total corruption of human nature] of human beings. This recognition of the sinfulness of humans provides a stimulus for exploring the unique contribution that sin discourses make to pluralistic public discussion.

A renewed look at the notion of deadly $\operatorname{sins}^{5}$, for instance, shows how the sin discourse can help us to reach more adequate descriptions of the wrongs in our societies, and consequently also of the potential remedies of those wrongs also with regard to poverty. Maybe the seven deadly sins that were developed by Evagrius of Pontus (346-399 AD), John Cassian (360-430 AD) Pope Gregory the Great (540-604 AD) and systematised by Thomas Aquinas (1224-1274 AD), and which mention one form of a sin, but imply various related forms of that $\sin$. These were related to the days of the week for the sake of prayer to be saved from those sins, and might facilitate deeper descriptions of the wrongs in society and of the remedies thereof.

Medieval Christians prayed for forgiveness for and salvation from a specific deadly sin on every day of the week. On Mondays they prayed to be freed of envy. It is difficult for humans not to be envious or jealous. It is difficult to rejoice with those who are honoured. This is true of individuals, cultural and ethnical groups, even of nations.

On Tuesdays they prayed to triumph over hate, anger and violence. If we pray this medieval prayer faithfully, we may lower our levels of road rage, and also various other forms of violence, from the extremely visible and crude, to the most subtle, almost unrecognisable forms.

5.For some helpful discussions of the deadly sins see R.K. de Young (2009) and S. Schimmel (1992). 
On Wednesdays they prayed for liberation from all forms of acedia [listlisness], apathy, nonchalance, lack of caring, inertia, lack of involvement, despondency, melancholy, emigration to within.

On Thursdays it was the turn of greed and avarice, or what today we would call consumerism, profiteering, selfenrichment, corruption, tenderpreneurism, fraud and the evil socio-economic chasm between South Africans.

On Fridays they prayed for salvation from gluttony. Gluttony is on the one hand to have in excess, to own and gather too much, and on the other hand to enjoy the good selfishly in isolation, excluding fellow humans and other groups.

Lust was addressed on Saturdays. Lust is the violation of the most precious gift God gives, the fellow human with his or her body, soul and spirit. Lust is the dehumanisation of a fellow human, the devaluation of someone else to the level of a sex object or machine for the satisfaction of pleasure, or the dehumanisation of someone for the sake of the pleasure of status, profit and power.

And on Sundays the focus was on pride. The medieval Christian logic means that on Sundays we go to church to confess who God really is, and to remember that we are not gods ourselves. A second example of the importance of thicker Christian convictions for moral discernment in pluralistic contexts is the view of De Villiers (1978:196) that the love of God in Jesus Christ constitutes both the foundation of our practices of love amongst each other and the central criterion for our moral choices and conduct. This notion of divine love that finds its culmination in the sacrificial death of Jesus Christ enriches public pluralistic debates about justice.

The Old Testament uses justice mainly in a twofold way, that is as forensic justice [mishpat] and as compassionate justice [tsedaqah]. The New Testament dikaiosune, carries both meanings. Bruce Birch (1991:155-156) describes mishpat as a term with a basic forensic character. It deals with judicial activities at every level. It is an ethical concept that deals with rights due to every individual in the community and with the upholding of those rights. Especially God's justice refers to the upholding of the rights of the vulnerable, and with the advocacy of their needs (Dt 10; 18; Ps 10:18; Jr 5:28). Where the rights of the vulnerable are violated, God's justice can be translated as judgement, the activity of God to hold accountable those who deny, manipulate and exploit the rights of others.

Tsedaqah, according to Birch (1991:153-154), is also translated as righteousness. Here the focus is on right relationships. God's righteousness refers to his concrete acts to establish and preserve relationship. His law is a gift that aims at establishing terms under which relationship is preserved and maintained. ${ }^{6}$ Both the Old and New Testaments teach that sacrifice was required to achieve this rightness in relations.

6.Tsedaqah can also be translated as vindication, deliverance, uprightness, right and even prosperity.
Justice therefore stands in relationship to justification. Justification means that we are declared righteous by God because of the ultimate sacrifice of Christ. This imputed righteousness, that is, righteousness that we possess because of our connectedness in faith to Christ, makes us people who practise justice. Those who are made righteous through a sacrifice also practice sacrificial justice. They know that relationships will not be right and prosperous and joyful ${ }^{7}$ without sacrifice.

Palestinian theologian, Naim Stifan Ateek (1989:142-143), argues that tsedaqah carries the meaning of kindness, compassion and mercy. God's concern for social justice grows out of his compassion and mercy. Ateek (1989) is afraid that when the forensic and sacrificial dimensions of justice are separated, the situation of injustice and brokenness might deteriorate:

Since, as result of the fall, the dichotomies lie within the fragmentation of the human being, people have a propensity to talk about justice in a strict sense, especially when they have fallen prey to injustice. The symbol of justice has become a blindfolded virgin carrying a scale in one hand and a sword in the other, rendering impartially to each person his or her due. In other words, justice is invoked as a totally uninvolved, independent, objective standard. Legally speaking, such a concept might satisfy human demands for justice, but it would leave much to be desired because there is a sense in which blind, impersonal, and exacting justice can easily become injustice. If strict justice were left to operate by itself, the line that separates it from injustice would be very thin indeed. It is, of course, quite understandable that humans who have been wronged usually demand that absolute justice be done. Absolute justice not only restores their rights but also has a way of condemning and humiliating the wrongdoer. Yet so often such an outcome leaves the persons, the human family, or the nation involved fragmented and lost. What we need in the Israel-Palestine conflict is a way in which justice can be exercised so that the ultimate result would be peace and reconciliation between and within each people and not the fragmentation and destruction of either or both. Our problem is that, while such positive results are innately naturally in God, they are alien in unredeemed humans. [p. 139]

These perspectives make it clear that we can advance the quests for defining and implementing justice in pluralistic societies if we view love as both the foundation and norm of justice as De Villiers seems to suggest.

\section{Participation in the technical prophetic discourse}

De Villiers (1999:36) often points out that serious technical analysis is a neglected mode of theological discourse in South Africa. In a society where a plurality of comprehensive religious and secular world views exist, and in a society where a plurality of often contradictory moral positions coexist - even within Christian communities, the strengthening of technical discourse is very important.

7.Reformed philosopher Nicholas Wolterstorff (1983:70) describes justice in terms efore of shalom and joy. 'But the peace which is shalom is not merely the absence of hostily, not merely being in right relationships. A nation may be at peace with allits neighbours and yet be miserable in its poverty. To dwell in shalom is to enjoy living before God, to enjoy living in one's physical surroundings, to enjoy living with one's fellows, to enjoy life with oneself.' 
James Gustafson (1988) offers a clear description of the technical discourse:

Ethical discourse provides the concepts, the modes of appropriate argumentation, and important distinctions which lead to greater precision and stronger backing for what Christians and other religious communities think is the right thing to do, the good thing to do. (p. 42)

Gustafson (1988:31-32) admires the constant attention to the ethical moral discourse in the Roman Catholic tradition. He argues that since the middle of the 20th century Protestant ethicists started to give attention to the ethical, technical or philosophical moral discourse. He mentions that the ethical writings of his teachers and of his pupils differ significantly in this regard. Ethical discourse, under the influence of especially Anglo-American moral philosophy, encourages a more precise use of concepts like justice, virtue, rights and duties. It offers more careful distinctions between concepts and classes of moral issues. It requires stronger logical arguments in support of moral prescriptions or moral condemnations.

Gustafson (1988:37-40) explains that prophets as technical, ethical or philosophical analysts are challenged to employ different ethical theories in a complementary manner in their analyses - as is done in the Bible, for example teleological (Aristotle, Augustine, Thomas Aquinas), deontological (Kant, Barth, Bultmann), utilitarian or consequentialist (Jeremy Bentham and John Stuart Mill) theories. In addition to the teleological (human as maker) and deontological (human as citizen) theories, H.R. Niebuhr calls for attention to the cathecontic (human as answerer) theory. Gustafson reckons that Protestant ethicists have a lot to learn from their colleagues in the Jewish, Catholic and, to some extent, Anglican traditions regarding the practice of constructive casuistry that is informed by philosophical insights and that employs a variety of ethical theories.

Brady (1998:146-147) mentions that the ethical discourse is drier and less exciting than the narrative and prophetic discourses. Ethics can be tedious. Wording must be painstakingly accurate. Concepts need to be defined in a clear, comprehensive and concise manner. Clear thinking, precise use of words, and compelling reasoning facilitate the engagement of theology with public life. The ethical discourse helps to make narratives public and translates the passionate pleas of the prophet into rationally defensible public positions. And by assisting these discourses to be more vocal and public in credible and constructive ways, an impact is made on the formation of public opinion, public thinking, public discourse, public ethos, public Zeitgeist and eventually on public policy.

In his ethical writings, as well as in his participation in discussions on public moral issues, De Villiers proves to be perhaps the South African theologian who, more than others, honours these parameters for ethical discourse. Over many years De Villiers had taken up the challenge to engage in technical discourses. He fulfilled this task in various ways. De Villiers (1999:37) pleads that we make Christian moral positions on public matters as far as possible intellectually accessible within Christian communities and to those outside the communities. Without compromising on our thicker theological convictions, we are challenged to explain those convictions in an accessible way to others, with the purpose to invite to conversation and to mutually enrich each other.

De Villiers $(1978 ; 2005: 528)$ also makes a strong plea that we seek consensus about moral convictions within and outside the Christian community. Together with Dirk Smit he (1996:31-47) spells out pathways towards consensus by means of an analysis and contextual application of Hans Eduard Tödt's various aspects, facets, Sachmomenten, Schritten, in the process of moral decision-making. Through intentional communal 'seeing', 'judging' and 'deciding and acting', which entails drinking from the broader perspectives of our thicker ${ }^{8}$ theological convictions, as well as thorough participation in technical analyses, we can make progress on the road of jointly discerning the will of God and of reaching moral consensus in pluralistic ecclesial and social contexts.

De Villiers consistently practices an ecclesial public theology. For him churches are crucial in the public theological endeavour. He specifically argues that we can impact on public discourses, public opinion-formation and public policy-making processes by means of seeking consensus on moral positions on public matters within congregations, denominations and especially ecumenical bodies.

De Villiers's apparent appreciation that the general revelation of God might imply that we also seek this consensus, as far as possible and where appropriate, with other religious views as well, in order to advance a joint religious voice in public life. Towards the end of his doctoral dissertation he (De Villiers 1978:219) asks for renewed attention to the notion of the general and specific revelation of God. In terms of God's general revelation the knowledge of good and bad that is expressed in so-called autonomous, secular moralities, comes from God. In this sense one can argue that religion, according to De Villiers, is also the mother of morality. This notion of general revelation even paves the way for stronger collaboration between Christians and people from other religious and secular world views, and comprehensive meaning-giving frameworks.

So when Christians enter public pluralistic debates they can do it in the awareness that their own knowledge of the wise, the right and the good, comes from God. They can engage with people from other religious convictions and with people from secular orientations in the awareness that their knowledge and insights about the good derives from the same God. This they can do without becoming religiously imperialistic and absolutistic. They can function with this knowledge in a humble way without even expressing this deeper conviction about God's general revelation explicitly. And they can enter discourses on moral and social issues in the knowledge that their religious convictions do make a difference to how they think about public moral issues.

8.For a very helpful, more recent, discussion in the field of political science of the notion of thickness and thinness in pluralistic public discourses, see B. Gregg (2003). 
The joint and communal decisions of churches, especially in their ecumenical existence and even also in their relationship with other religious faiths, are perhaps an indispensable mode of participation in public discourses in pluralistic societies. This is indeed a neglected dimension of our public theological labour. This challenge posed by De Villiers needs our serious attention.

\section{Conclusion}

De Villiers has served public theology in South Africa for decades. His work offers various impulses for developing faithful Christian prophetic involvement in pluralistic public discourses. We are glad that he will, by God's grace, pursue with us these impulses for years to come. His involvement in the Centre for Public Theology at the University of Pretoria and some of his latest works convince us that this will indeed be the case (2011a, 2011b)!

\section{Acknowledgements Competing interests}

The author declares that he has no financial or personal relationship(s) which may have inappropriately influenced him in writing this paper.

\section{References}

Ateek, N.S., 1989, Justice and only justice. A Palestinian theology of liberation, Orbis Books, New York.

Birch, B.C., 1991, Let justice roll down. The Old Testament, ethics, and Christian life, Westminster John Knox Press, Louisville.

Brady, B.V., 1998, The moral bond of community. Justice and discourse in Christian morality, Georgetown University Press, Washington.

De Villiers, D.E., 1978, Die eiesoortigheid van die Christelike moral, Rodopi, Amsterdam.

De Villiers, D.E., 1995, 'Die Nederduitse Gereformeerde Kerk en die nuwe situasie in die samelewing', Nederduits Gereformeerde Teologiese Tydskrif XXXVII(4), 558-569.
De Villiers, D.E., 1999, 'Die NG Kerk en die oorgang na 'n nuwe Suid-Afrika', Skrif en Kerk 20(1), 15-38.

De Villiers, D.E., 2005, 'The vocation of reformed ethicist in the present South African society', Scriptura 89, 521-535.

De Villiers, D.E., 2011a, 'Public Theology in the South African context', International Journal of Public Theology 5, 5-22. http://dx.doi.org/10.1163/156973211X543715

De Villiers, D.E., 2011b, 'South African Public Theology in a global era' International Journal of Public Theology 5, Special issue (guest editor: D.E. de Villiers).

De Villiers, D.E. \& Smit, D.J., 1996, 'Waarom verskil ons so oor wat die wil van God is? Opmerkings oor Christelike morele oordeelsvorming', Skrif en Kerk 17(1), 31-37.

De Young, R.K., 2009, Glittering vices. A new look at the seven deadly sins and their remedies, Brazos Press, Grand Rapids.

Gregg, B., 2003, Thick moralities, thin politics. Social integration across communities of belief, Duke University Press, Durham/London.

Gustafson, J., 1988, Varieties of moral discourse: Prophetic, narrative, ethical, and policy, s.n., Grand Rapids. (Stob lectures of Calvin College and Seminary).

Koopman, N.N., 2004, 'The role of tradition in moral decision-making and mora consensus', Nederduits Gereformeerde Teologiese Tydskrif 45, 838-848.

Koopman, N.N., 2009, 'Public Theology as Prophetic Theology. More than utopianism and criticism', Journal of Theology for Southern Africa 134, July, 117-130.

Koopman, N.N., 2010, 'Churches and public policy discourses in South Africa', Journal of Theology for Southern Africa 136, March, 41-56.

Kuitert, H.M., 1974a, 'Het Schriftberoep in de ethiek', in H.M. Kuitert (red.), Anders gezegd. Een versameling van opstellen voor de welwillende leze, 4th edn., pp. 63-87, Kok, Kampen.

Kuitert, H.M., 1974b, Zonder geloof vaart niemand wel. Een plaatsbepaling van Christendom en Kerk. Ten Have, Baarn.

Kuitert, H.M., 1981, 'De rol van de bijbel in de protestante theologische ethiek', Gereformeerd Theologisch Tijdschrift 81, 65-82.

Kuitert, H.M., 1984, 'Spelen godsdienstige overtuigingen een rol bij de morele oordeelsvorming?', in A.W. Musschenga (red.), Onderwijs in natuurwetenschappen en morele vorming. Opstellen over wetenschaps-filosofie, theologie, antropologie en ethiek voor het natuurwetenschappelijk onderwijs, pp. 206-219, Ten Hawe, Amsterdam.

Kuitert, H.M., 1985, Alles is politiek, maar politiek is niet alles. Een theologisch perspectief op geloof en politiek, Ten Have, Baarn.

Kuitert, H.M., 1988a, Filosofie van de theologie, Serie Wetenschaps-filosofie, Martinus Nijhoff, Leiden.

Kuitert, H.M., 1988b, 'Morele consensus: mogelijkheden en grenzen', in I.G. De Beaufort \& H.M. Dupuis (reds.), Handboek Gezondheids-ethiek, pp. 29-40, Van Gorcum, Assen-Maastricht.

Kuitert, H.M., 1988c, 'Secularisatie en moraal', in G. Dekker \& U. Gäbler (reds.), Secularisatie in theologisch perspectief, pp. 131-148, Kok, Kampen.

Musschenga, A.W., 1989, 'De universele moraal als opdracht', in K. Gäbler et al. (reds.) Geloof dat te denken geeft. Opstellen aangeboden aan Prof. dr. H.M.Kuitert, pp.159-178, Ten Have, Baarn.

Schimmel, S., 1992, The seven deadly sins. Jewish, Christian, and classical reflections on human nature, The Free Press, New York.

Wolterstorff, N., 1983, Until Justice and Peace Embrace, Eerdmans, Grand Rapids. 